\title{
PELATIHAN MOTIVASI DIRI PELAJAR SMA SEBAGAI UPAYA MENINGKATKAN PARTISIPASI DALAM MENGHADAPI TUGAS KELOMPOK
}

\author{
Kimmy Katkar 1, Pundani Eki Pratiwi ${ }^{2}$, Purwaningtyastuti ${ }^{3}$, Anna Dian Savitri 4 \\ 1 Fakultas Psikologi Universitas Semarang, kimmy@usm.ac.id, Semarang, Indonesia \\ 2 Fakultas Psikologi Universitas Semarang,pund89@gmail.com,Semarang, Indonesia \\ 3 Fakultas Psikologi Universitas Semarang, pungkycute14@gmail.com, Semarang, \\ Indonesia \\ ${ }^{4}$ Fakultas Psikologi Universitas Semarang, dsavie@usm.ac.id, Semarang, Indonesia
}

\begin{abstract}
ABSTRAK
Tugas kelompok merupakan salah satu bentuk proses untuk mengembangkan kompetensi diri dengan adanya tanggung jawab dari setiap anggota kelompok. Namun karena kurangnya motivasi diri bisa mendorong munculnya sikap pasif pada individu saat berada dalam kelompok. Sikap pasif yang dilakukan dapat berkembang menjadi emosi negatif karena tidak adilnya pembagian tugas yang dikerjakan dan pada akhirnya dapat menyebabkan hasil kerja kelompok menjadi tidak maksimal. Tujuan dari kegiatan pengabdian ini adalah untuk membantu meningkatkan motivasi diri sebagai upaya meningkatkan partisipasi dalam menghadapi tugas kelompok. Metode pelaksanaan dalam kegiatan pengabdian ini dilakukan secara online melalui media zoom dengan diberikan ceramah, studi kasus dan game. Kegiatan dievaluasi dengan menggunakan model pengukuran pretest dan post-test. Berdasarkan hasil analisa dengan menggunakan metode pengkodean deskriptif didapatkan ada peningkatan motivasi diri pada pelajar dari sebelum dan setelah diberikan pelatihan. Kegiatan yang sudah dilakukan sangat bermanfaat bagi pelajar, dengan adanya peningkatan motivasi diri sehingga pelajar lebih termotivasi untuk aktif berpartisipasi dalam mengikuti segala aktivitas proses pembelajaran termasuk mengerjskan tugas kelompok.
\end{abstract}

Kata kunci: Motivasi; Partisipasi; Pelajar; Tugas Kelompok

\section{PENDAHULUAN}

Manusia sebagai makhluk sosial pada dasarnya tidak terlepas dari kehidupan berkelompok. Pengelompokan-pengelompokan antar individu sebagai hal yang tidak terhindarkan dan akan terus terjadi di lingkungan masyarakat. Hampir setiap hari semua manusia akan saling berinteraksi sosial dalam suatu kelompok dan dengan kelompok lain. Baik itu interaksi dalam lingkup keluarga, pertemanan ataupun interaksi pada saat beraktivitas di luar. Hidup dalam kelompok dapat memengaruhi kualitas hidup individu secara menyeluruh dan dapat diterapkan dalam berbagai bidang kehidupan. Salah satunya adalah bidang pendidikan. Di tengah situasi pandemi seperti sekarang ini banyak terjadi perubahan metode proses pembelajaran yaitu dari yang semula pembelajaran dilakukan secara offline, namun sekarang ini sudah berubah menjadi online. 
Salah satu kegiatan yang erat kaitannya dengan siswa adalah mengerjakan tugas yang diberikan oleh guru. Tugas dapat dibedakan menjadi dua, yaitu tugas individu dan tugas kelompok. Tugas kelompok mempunyai beban yang lebih besar dan membutuhkan kontribusi dari setiap anggota kelompok agar tugas tersebut dapat terselesaikan dengan baik. Namun terkadang bekerja secara kelompok menjadi tidak efektif karena tidak semua anggota kelompok memiliki kesadaran akan tanggung jawab terhadap tugas kelompok tersebut. Salah satu kegagalan dari tugas kelompok ini adalah ketika terjadi kemalasan sosial (social loafing).

Fenomena ini merujuk pada menurunnya usaha individu ketika berada dalam kelompok dibandingkan ketika individu bekerja secara sendirian (Baron, R.A \& Byrne, 2005). Kemalasan sosial sebagai kecenderungan bagi orang-orang untuk mengeluarkan usaha yang lebih sedikit ketika mereka mengumpulkan usaha mereka untuk mencapai suatu tujuan yang sama dibandingkan jika mereka secara individual akan diperhitungkan (Myers. D.G, 2012). Kemalasan sosial dapat terjadi karena dua faktor baik intrinsik maupun ekstrinsik. Rasa malas yang timbul secara intrinsik disebabkan karena tidak adanya motivasi diri dan kelelahan dalam beraktivitas (Moslem et al., 2019).

Rasa malas ini apabila muncul pada saat siswa mendapatkan tugas kelompok akan memunculkan perilaku kemalasan sosial (social loafing) yang mendorong individu untuk enggan ikut berpartisipasi dalam kerja kelompok. Menurut Geen (Sarwono \& Meinarno, 2015) penyebab kemalasan sosial salah satunya adalah evaluation apprehension yakni mengenai kehadiran orang lain dalam kelompok menimbulkan situasi anonim. Hal ini terjadi karena banyaknya anggota dalam suatu kelompok, sehingga terdapat anggota yang pasif atau bahkan tidak termotivasi sama sekali dalam proses pembuatan tugas kelompok, kurang atau tidak adanya kekohesifan antar anggota kelompok dan ingin menumpang keberhasilan dengan orang lain.

Aspek-aspek kemalasan sosial dari (Myers. D.G, 2012), diantaranya adalah menurunnya motivasi individu untuk terlibat dalam kegiatan kelompok. Seseorang menjadi kurang termotivasi untuk terlibat atau melakukan suatu kegiatan tertentu pada saat orang tersebut berada dalam keadaan bersama dengan orang lain. Kedua sikap pasif, anggota kelompok lebih memilih untuk diam dan memberikan kesempatan kepada orang lain untuk melakukan usaha kelompok. Sikap pasif ini didorong oleh adanya anggapan bahwa tujuan kelompok telah dapat dipenuhi oleh partisipasi orang lain dalam kelompok tersebut. Ketiga pelebaran tanggung jawab, usaha untuk mencapai tujuan kelompok merupakan usaha yang dilakukan oleh para anggotanya. Setiap anggota kelompok bertanggung jawab akan keberhasilan pencapaian tujuan tersebut. 
Keadaan ini mengakibatkan munculnya pelebaran tanggung jawab dimana individu yang merasa dirinya telah memberikan kontribusi yang memadai bagi kelompok tidak bergerak untuk memberikan konstribusinya lagi dan akan menunggu partisipasi anggota lain untuk menyelesaikan tanggung jawab kelompok. Keempat free ride atau menumpang pada usaha orang lain, individu yang memahami bahwa masih ada orang lain yang mau melakukan usaha kelompok cenderung untuk menumpang (free ride) begitu saja pada anggota lain tanpa perlu bersusah payah melakukan usaha. Terakhir penurunan kesadaran akan evaluasi dari orang lain, kemalasan sosial dapat juga terjadi karena dalam situasi kelompok terjadi penurunan pada pemahaman atau kesadaran akan evaluasi dari orang lain (evaluation apprehension) terhadap dirinya.

Bekerja dalam sebuah kelompok merupakan kesempatan baik bagi siswa untuk mendapatkan pengalaman belajar dalam mengembangkan kemampuan komunikasi dan kemampuan untuk bekerja dalam kelompok (Hall, D., 2012). Namun tidak semua individu memiliki pola pikir positif seperti itu, banyak individu yang justru merasa malas dan ingin menumpang keberhasilan dari hasil pekerjaan anggota lain. Guru BK menyatakan bahwa terdapat siswa yang tidak menyukai pemberian tugas kelompok karena di dalam kelompok tersebut tidak terdapat sahabatnya dan memiliki teman yang tidak menyukai dirinya di dalam kelompok. Sehingga terjadi penurunan motivasi individu untuk terlibat dalam pengerjaan tugas kelompok. Sesuai dengan (Sasmita et al., 2019) bahwa dalam suatu kelompok juga terdapat sifat pasif dimana adanya anggota kelompok yang memberikan kesempatan kepada anggota kelompok lain untuk maju terlebih dahulu karena kelompok tersebut tidak memiliki motivasi untuk menyelesaikan tugas tepat waktu juga tidak ada kekompakkan antar anggota kelompok yang berpengaruh terhadap hasil akhir tugas kelompok tersebut.

Menurut Mc Donald dalam (Kompri, 2016) motivasi adalah suatu perubahan energi di dalam pribadi seseorang yang ditandai dengan timbulnya afektif (perasaan) dan reaksi untuk mencapai tujuan. Dengan demikian munculnya motivasi ditandai dengan adanya perubahan energi dalam diri seseorang yang disadari atau tidak. Terdapat dua fungsi motivasi dalam proses pembelajaran yang dikemukakan (Sanjaya, 2010) pertama, dapat mendorong siswa untuk beraktivitas. Perilaku setiap orang disebabkan karena dorongan yang muncul dari dalam yang disebut dengan motivasi. Besar kecilnya semangat seseorang untuk bekerja sangat ditentukan oleh besar kecilnya motivasi orang tersebut. Kedua sebagai pengarah, perilaku yang ditunjukkan setiap individu pada dasarnya diarahkan untuk memenuhi kebutuhannya atau untuk mencapai tujuan yang telah ditentukan.

Perilaku kemalasan sosial muncul karena individu memiliki kepercayaan bahwa tugas atau pekerjaan di dalam kelompok telah atau akan dikerjakan oleh 
anggota yang lain (Putri \& Iswinarti, 2020). Harapan individu akan usaha anggota kelompok lain muncul karena adanya hubungan sosial antar anggota dalam kelompok. Kemalasan sosial terjadi karena menurunnya motivasi seseorang untuk berpartisipasi dalam kerja kelompok. Sesuai dengan (Dewi, 2017) semakin tinggi motivasi yang dimiliki individu, maka semakin rendah perilaku kemalasan sosial. Dengan demikian, individu yang memiliki motivasi diri tinggi akan bertanggung jawab penuh atas pekerjaannya dengan ikut berpartisipasi dalam mengerjakan tugas kelompok.

Kemalasan sosial dapat terjadi karena adanya pengaruh motivasi individu (Paksi et al., 2020). Hal ini sesuai dengan pernyataan yang dikemukakan oleh guru BK bahwa fenomena kemalasan sosial masih sering terjadi saat guru memberikan tugas kelompok terlebih selama proses pembelajaran daring. Para guru kurang bisa mengevaluasi siswa mana yang tidak ikut kontribusi dalam mengerjakan tugas kelompok tersebut. Hal ini terlihat ketika tugas tersebut dipresentasikan, sehingga guru pun bisa mengetahui siswa mana yang betul-betul mengerjakan tugasnya dan yang hanya menumpang usaha temannya saja. Tujuan kegiatan pengabdian ini adalah memberikan pemahaman serta informasi yang dibutuhkan terkait bagaimana strategi meningkatkan motivasi diri sehingga siswa bisa aktif berpartisipasi dalam menghadapi tugas kelompok.

\section{METODE}

Pelaksanaan program kegiatan pengabdian kepada masyarakat dilaksanakan pada hari Rabu tanggal 03 November 2021. Pelatihan ini diikuti oleh 30 pelajar putra putri kelas X1 1 IPA di SMA Kesatrian 2 Semarang. Bapak Fiki selaku guru bimbingan konseling turut serta mendampingi mulai dari awal kegiatan sampai selesai. Kegiatan pengabdian berbentuk program pelatihan yaitu berupa pelatihan mengenai bagaimana strategi untuk meningkatkan motivasi diri pada masing-masing siswa agar bisa lebih berpartisipasi dalam menghadapi tugas kelompok.

Kegiatan pengabdian berlangsung sekali selama 90 menit. Kegiatan dievaluasi dengan menggunakan model pengukuran pre-test dan post-test yang akan dianalisis secara deskriptif dengan menggunakan metode kualitatif. Pre-test diberikan sebelum pelatihan dan post-test diberikan setelah pelatihan. Teknik pengolahan data dilakukan menggunakan pengkodean deskriptif, dimana peneliti hanya meringkas pesan dari sebuah bagian kecil data kualitatif dalam sebuah kata atau frasa pendek (Saldana, 2009). 


\section{Adapun bentuk pelaksanaan pengabdian yaitu sebagai berikut :}

a. Ceramah: diberikan sebagai pengantar pelatihan. Dalam sesi ceramah ini dibagi menjadi tiga tahap. Pertama, diberikan ceramah sebagai sarana pemberian informasi terkait dengan gambaran dan makna pentingnya motivasi diri. Ceramah selanjutnya adalah membahas mengenai pentingnya partisipasi dari masing-masing anggota kelompok saat dihadapkan pada situasi tugas kelompok. Sedangkan ceramah terakhir membahas mengenai bagaimana cara meningkatkan motivasi diri pada masing-masing pelajar.

b. Pelatihan: Pelatihan diberikan setelah sesi ceramah, yaitu latihan yang ditunjukkan melalui pemberian sebuah game dan analisa kasus secara individu maupun kelompok.

c. Tanya Jawab dan Evaluasi: dilakukan bersama, sebagai penguatan dan saling tukar pengalaman dalam menghadapi sebuah permasalahan dalam lingkup proses pembelajaran di sekolah. Selain itu melalui diskusi dan sharing, sesi ini juga menjadi sesi evaluasi terkait dengan pelaksanaan dan isi materi.

\section{HASIL DAN DISKUSI}

Berdasarkan hasil pre-test dan post-test terkait pelatihan motivasi diri pelajar SMA, diketahui terdapat perbedaan mengenai tingkatan motivasi diri pelajar dari sebelum dan sesudah diberikan pelatihan.

Tabel 1. Hasil Pre-Test dan Post-Test

\begin{tabular}{|c|c|c|}
\hline Kuesioner & Pre-test & Post-test \\
\hline $\begin{array}{l}\text { Mengapa motivasi diri perlu } \\
\text { dimiliki oleh seorang siswa? }\end{array}$ & $\begin{array}{l}\text { Agar menjadi siswa } \\
\text { berprestasi dan } \\
\text { teladan }\end{array}$ & $\begin{array}{l}\text { Agar menjadi siswa } \\
\text { berprestasi, rajin dan } \\
\text { dapat selalu aktif } \\
\text { berpartisipasi dalam } \\
\text { tugas kelompok }\end{array}$ \\
\hline $\begin{array}{l}\text { Apa yang dimaksud dengan } \\
\text { kemalasan sosial? }\end{array}$ & $\begin{array}{l}\text { Malas } \\
\text { mengerjakan } \\
\text { sesuatu }\end{array}$ & $\begin{array}{ll}\text { Pasif } & \text { dalam } \\
\text { mengerjakan tugas } \\
\text { kelompok }\end{array}$ \\
\hline $\begin{array}{l}\text { Apa peran Anda dalam proses } \\
\text { pengerjaan tugas kelompok? }\end{array}$ & Anggota & $\begin{array}{l}\text { Ketua dan anggota } \\
\text { yang } \\
\text { berpartisipasi } \\
\text { setiap } \\
\text { kelompok }\end{array}$ \\
\hline
\end{tabular}




\begin{tabular}{|c|c|c|}
\hline $\begin{array}{l}\text { Bagaimana strategi Anda dalam } \\
\text { mengerjakan tugas kelompok } \\
\text { yang diberikan oleh guru? }\end{array}$ & $\begin{array}{l}\text { Dengan membagi- } \\
\text { bagi tugas }\end{array}$ & $\begin{array}{l}\text { Mengkoordinir, } \\
\text { membagi tugas dan } \\
\text { komunikasi secara } \\
\text { intens }\end{array}$ \\
\hline $\begin{array}{l}\text { Faktor-faktor apa saja yang } \\
\text { menjadi poin penting dalam } \\
\text { mengerjakan tugas kelompok? }\end{array}$ & $\begin{array}{l}\text { Kerja sama dan } \\
\text { kekompakan }\end{array}$ & $\begin{array}{l}\text { Kerja sama, saling } \\
\text { pengertian, } \\
\text { tanggung jawab dan } \\
\text { kompak }\end{array}$ \\
\hline $\begin{array}{l}\text { Apa dampak negatif dari } \\
\text { kemalasan sosial bagi siswa? }\end{array}$ & $\begin{array}{l}\text { Siswa menjadi } \\
\text { malas belajar dan } \\
\text { malas } \\
\text { mengerjakan } \\
\text { tugas }\end{array}$ & $\begin{array}{l}\text { Potensi individu tidak } \\
\text { bisa berkembang, } \\
\text { merusak hubungan } \\
\text { sosial, hasil tugas } \\
\text { menjadi tidak } \\
\text { maksimal }\end{array}$ \\
\hline $\begin{array}{l}\text { Bagaimana caranya agar bisa } \\
\text { terhindar dari perilaku kemalasan } \\
\text { sosial? }\end{array}$ & $\begin{array}{l}\text { Dengan } \\
\text { membangun } \\
\text { semangat belajar } \\
\text { dan beraktivitas }\end{array}$ & $\begin{array}{l}\text { Meningkatkan } \\
\text { motivasi diri, selalu } \\
\text { berpikir positif dan } \\
\text { optimis, penuh } \\
\text { dengan perasaan } \\
\text { tanggung jawab }\end{array}$ \\
\hline $\begin{array}{l}\text { Bagaimana cara meningkatkan } \\
\text { motivasi diri ? }\end{array}$ & $\begin{array}{l}\text { Memiliki rasa } \\
\text { tanggung jawab, } \\
\text { punya tujuan jelas, } \\
\text { selalu berpikir } \\
\text { positif }\end{array}$ & $\begin{array}{l}\text { Selalu termotivasi } \\
\text { dalam melakukan } \\
\text { segala hal positif, } \\
\text { berhenti } \\
\text { membandingkan diri } \\
\text { dengan orang lain, } \\
\text { tentukan tujuan, } \\
\text { berpikir positif, } \\
\text { memberikan punishm } \\
\text { ent dan reward untuk } \\
\text { diri sendiri }\end{array}$ \\
\hline
\end{tabular}

Hasil analisis data menggunakan pengkodean deskriptif menunjukkan adanya peningkatan motivasi diri pada pelajar. Hal ini terlihat dari saat sebelum diberikan pelatihan, para pelajar menganggap bahwa tugas kelompok merupakan suatu hal yang kurang menyenangkan karena kurang adanya kerja sama dalam menyelesaikan tugas tersebut. Rata-rata para pelajar menyebutkan bahwa akar permasalahan yang banyak muncul dalam pengerjaan tugas kelompok yaitu 
mengenai kontribusi yang diberikan oleh masing-masing anggota kelompok berbedabeda (KB/S1/W1/B.42-44).

Siswa cenderung memilih bersikap pasif, ada pula yang lebih sedikit mengeluarkan usaha dalam menyelesaikan tugas (KB/S3/W1/B.40-42). Terjadi penurunan bahkan hilangnya motivasi diri menjadikan salah satu faktor pendorong kurang berpartisipasinya anggota kelompok dalam menyelesaikan tugas (KB/S2/W1/B.45-47). Terdapat beberapa siswa yang mengerjakan tugas seadanya karena tidak mengerti dengan apa yang harus dikerjakan dan juga merasa kesulitan membuat tugas sehingga merasa malas untuk mengerjakannya (KB/S5/W1/B.39-43). Ada pula siswa yang hanya mengerjakan sesuai instruksi teman kelompok yang lain, jadi hanya mengerjakan bagiannya saja, tidak peduli teman kelompok yang lain sudah selesai atau belum (KB/S4/W1/B.18-22).

Peranan siswa dalam mengerjakan tugas kelompok berbeda-beda ada individu yang aktif berpartisipasi sampai akhir, ada yang berpartisipasi sampai setengah saja sisanya bersikap pasif (KB/S7/W1/B.42-44). Beberapa individu ada yang tidak terlalu peduli dengan tugas kelompok karena merasa kontribusinya tidak terlalu diamati dengan detail (KB/S9/W1/B.18-20). Sebagian pelajar yang tidak mengerti dengan tugas kelompok dan tidak tahu harus mengerjakan apa, serta tidak berusaha untuk memahami tugas kelompok yang diberikan akan lebih memilih untuk berdiam diri (KB/S11/W1/B.18-22).

Selain itu terdapat siswa yang menyatakan pernah mengalami konflik ketika bekerja dalam kelompok, konflik yang terjadi karena ada anggota yang menganggap tugas terlalu sulit dan dia tidak mampu untuk berkontribusi, sebaliknya anggota lain ada yang menganggap tugas terlalu mudah sehingga tidak perlu berkontribusi dalam pengerjaan tugas kelompok (KB/S8/W1/B.35-41). Pendapat serupa juga dikemukakan oleh siswa saat bekerja kelompok, terdapat beberapa temannya yang cenderung tidak berpartisipasi sama sekali dalam proses penyelesaian tugas karena melihat dalam kelompoknya terdapat anggota kelompok yang dianggap pandai dan mampu mengerjakan tugas tanpa banyak membutuhkan kontribusi dari anggota lainnya (KB/S4/W1/B.34-38).

Setelah diberikan pelatihan para pelajar merasa lebih termotivasi saat dihadapkan pada situasi tugas kelompok dan memiliki strategi untuk mengatasi anggota kelompok yang tidak ikut berpartisipasi dalam menyelesaikan tugas. Pelajar mampu memahami makna pentingnya seorang individu memiliki motivasi diri yang tinggi karena dengan memiliki motivasi, mereka akan lebih bisa bekerja dalam 
kelompok tanpa ada emosi negatif di dalamnya (KB/S3/W1/B.7-10). Dengan memberikan kontribusi ketika bekerja di dalam kelompok maka dapat menunjukkan prestasi yang dimiliki kepada rekan-rekan kerjanya maupun orang lain dan membuktikan pada diri sendiri bahwa bisa berprestasi (KB/S1/W1/B.8-11).

Pendapat serupa juga dikemukakan oleh siswa lain bahwa dengan ikut berpartisipasi dalam mengerjakan tugas kelompok, maka akan menjauhkan diri dari sikap malas dan membantu mengembangkan potensi diri (KB/S10/W1/B.52-54). Pentingnya memiliki motivasi diri bagi seorang pelajar adalah sebagai penguat dan penyemangat dalam mengikuti proses kegiatan pembelajaran yang selama ini cukup membuat jenuh siswanya karena dilakukan secara daring dalam kurun waktu cukup lama (KB/S15/W1/B.7-10).

\section{PEMBAHASAN}

Partisipasi merupakan bentuk usaha penyelesaian tugas secara berkelompok. Besar kecilnya dari kontribusi dapat tergantung dari pembagian tugas maupun kesadaran dari masing-masing anggota kelompok. Permasalahan yang sering muncul dalam kontribusi pengerjaan tugas kelompok yaitu adanya anggota yang kurang bahkan sama sekali tidak memberikan kontribusi yang akhirnya menjadikan beban bagi anggota kelompok yang lainnya (Kotimah \& laksmiwati, 2021). Hal ini sesuai dengan hasil survei yang menyebutkan bahwa pelajar merasa anggota kelompoknya kurang memberikan kontribusi bahkan ada pula yang tidak memberikan kontribusi sama sekali. Salah satu contoh kontribusi yang kurang dari anggota kelompok ditunjukkan melalui tidak adanya saran dan inisiatif ketika mengerjakan tugas.

Kebanyakan siswa menjadi merasa terbebani ketika mendapatkan anggota kelompok yang kurang berkontribusi, karena harus bekerja lebih agar hasil tugas tetap maksimal. Para pelajar memandang bahwa motivasi penting dimiliki bagi seorang pelajar, dengan tujuan agar siswa memiliki prestasi akademik yang tinggi. Hal ini sesuai dengan (Mudjiono, 2006) bahwa motivasi belajar siswa dapat menurun, kurangnya motivasi atau tidak adanya motivasi diri akan menurunkan semangat dalam menjalani kegiatan pembelajaran, sehingga mutu hasil belajar menjadi rendah. Oleh karena itu, motivasi pada diri siswa perlu diperkuat terus menerus. Dengan tujuan agar siswa yang mempunyai motivasi diri tinggi, hasil belajar yang diraihnya dapat tercapai maksimal.

Motivasi diri berperan penting dalam proses belajar yaitu dapat memberikan semangat dan rasa senang dalam belajar sehingga siswa yang mempunyai motivasi diri tinggi akan mempunyai energi positif untuk melaksanakan kegiatan belajar 
(Aspian, 2018). Sesuai pernyataan pelajar bahwa jika individu memiliki motivasi dalam dirinya, maka individu tersebut akan merasa selalu semangat dan terdapat keinginan berpartisipasi dalam mengikuti segala kegiatan di sekolah. Namun, tidak semua siswa memiliki motivasi yang tinggi, adapula siswa yang tingkat motivasinya rendah sehingga mereka kurang semangat dalam belajar. Motivasi dapat dipengaruhi oleh dua faktor yaitu faktor intrinsik dan faktor ekstrinsik (Aspian, 2018). Faktor intrinsik merupakan hal-hal yang dapat mempengaruhi motivasi yang berasal dari dalam diri sendiri, misalnya seperti adanya kemauan dari dalam diri untuk terus berkembang, sedangkan faktor ekstrinsik merupakan hal-hal yang dapat mempengaruhi adanya motivasi yang berasal dari luar individu itu sendiri, misalnya seperti dorongan dari orang tua, teman dan guru.

Dalam mengerjakan tugas kelompok, terdapat beberapa anggota lainnya hanya berdiam diri tidak mengusulkan sebuah ide maupun ikut kontribusi dalam mengerjakan tugas kelompok. Sehingga membuat anggota kelompok lainnya untuk bekerja lebih keras sebagai pengganti temannya yang seharusnya mengerjakan tugas tersebut. Sesuai dengan (Taylor et al, 2012) bahwa dalam sebuah kelompok jika terdapat anggota kelompok yang bersikap pasif dan tidak berpartisipasi sama sekali, maka salah seorang anggota kelompok akan melakukan usaha lebih besar untuk menggantikan usaha anggota lain dalam kelompok.

Timbul perasaan tidak suka dan kecewa terhadap temannya yang tidak ikut berpartisipasi dalam mengerjakan tugas kelompok, sering dirasakan oleh beberapa pelajar yang mengalami hal serupa. Hal ini sesuai dengan pendapat (Krisnasari \& Tjahjo Purnomo, 2017) dampak negatif yang muncul dari perilaku kemalasan sosial dapat menjadi sebuah masalah karena dapat menimbulkan kekecewaan pada siswa saat bekerja dalam kelompok. Selain itu kemalasan sosial yang dilakukan oleh individu menyebabkan kurangnya kelekatan dalam menjalin hubungan pertemanan serta dapat menurunkan motivasi anggota kelompok lain, karena melihat anggota lainnya hanya menumpang dari usaha yang dilakukan orang lain. Maka anggota lainnya sebagian akan melakukan hal yang sama. Hal ini sesuai dengan pendapat (Luo et al., 2021) individu yang cenderung pasif dan bermalas-malasan dalam suatu kelompok akan berdampak buruk pada hubungan sosialnya serta dapat menurunkan motivasi bagi anggota lain.

Para pelajar merasa bahwa motivasinya cenderung menurun dan tidak semangat saat harus bekerja sama dengan anggota yang cenderung tidak mau berpartisipasi dalam tugas. Sesuai (Xiangyu et al, 2014) bekerja secara bersama dalam 
kelompok dapat mengurangi motivasi dan usaha individu. Sedangkan bagi individu yang memiliki motivasi diri tinggi memiliki kecenderungan untuk menyelesaikan segala sesuatu dengan baik, memiliki tanggung jawab terhadap kewajibannya, mampu untuk menemukan solusi terhadap masalah, kendala ataupun rintangan, dapat menerima umpan balik dan selalu tertarik dengan hal-hal yang cukup menantang. Sesuai dengan pernyataan (Taiyeb et al., 2012) Individu yang memiliki kebutuhan motivasi diri tinggi cenderung termotivasi dengan situasi yang penuh tantangan dan persaingan meski dalam situasi kelompok sekalipun.

\section{KESIMPULAN}

Hasil kegiatan PKM menunjukkan bahwa terdapat perbedaan hasil antara pretest dengan post-test. Hal ini dapat diartikan bahwa terjadi peningkatan motivasi diri pada pelajar dari sebelum dan sesudah diberikan pelatihan. Melihat hal ini, membuktikan bahwa kegiatan bermanfaat dan dibutuhkan oleh pelajar kelas XII IPA karena setiap individu mendapatkan pengetahuan baru yang mana sebelum adanya kegiatan ini siswa tidak mengetahui sama sekali makna pentingnya individu memiliki kemampuan motivasi serta manfaat yang di dapatkan adalah pelajar bisa menjadi individu yang selalu termotivasi dalam melakukan berbagai macam kegiatan positif dan mengetahui strategi-strategi untuk meningkatkan motivasi diri yang mudah diterapkan dalam lingkungan sosial.

\section{UCAPAN TERIMA KASIH}

Ucapan terimakasih atas terlaksananya kegiatan pengabdian ini disampaikan kepada:

1. Bapak Iswoyo, S.Pt, M.P, selaku Kepala LPPM Universitas Semarangyang telah memberikan kesempatan melakukan pengabdian.

2. Dr. Lucia Rini Sugiarti, S.Ps, M.Si, Psikolog selaku Dekan Fakultas PsikologiUniversitas Semarang yang telah memberikan dukungan kepada tim pengabdian.

3. Bapak Drs. Sunarno, M.Si, selaku kepala sekolah SMA Kesatrian 2 Semarang yang telah memberikan tempat, kesempatan dan izin untuk melaksanakan program pengabdian.

4. Bapak Fiki, M.Pd, selaku guru bimbingan konseling SMA Kesatrian 2 Semarang yang telah menyediakan waktunya untuk mendampingi dan belajar bersama.

5. Siswa kelas XII IPA SMA Kesatrian 2 Semarang yang telah bersedia menjadi subjek kegiatan pengabdian. 


\section{REFERENSI}

Aspian. (2018). Menumbuhkan Motivasi Belajar dalam Rangka Perbaikan Hasil Belajar Peserta Didik Aspian. Shautut Tarbiyah, 1-18.

Baron, R.A \& Byrne, D. (2005). Psikologi sosial. Buku 1 (10th ed.). Erlangga.

Dewi, S. S. (2017). Hubungan Motivasi Berprestasi dengan Social Loafing pada Mahasiswa Psikologi Universitas Medan Area. Consilium, 4(4), 106-121.

Gita Ayuningtyas Putri, Iswinarti, I. (2020). Self Esteem and Social Loafing on LSO ( Lembaga Semi Otonom ) Students. Jurnal Psikogenesis, 8(2), 229-240.

Hall, D., \& B. S. (2012). The Problem of Free-Riding Ingroup Projects: Looking Beyond Social Loafing as Reason for Non-contribution. Active Learning in Higher Education, $14(1), 37-49$.

Kompri. (2016). Motivasi Pembelajaran Perspektif Guru dan Siswa. PT Rosda Karya.

Kotimah \& Laksmiwati. (2021). Hubungan antara Kohesivitas Kelompok dengan Kecenderungan Social Loafing pada Mahasiswa Selama Masa Pembelajaran Daring HUBUNGAN ANTARA KOHESIVITAS KELOMPOK DENGAN KECENDERUNGAN SOCIAL LOAFING PADA MAHASISWA SELAMA MASA PEMBELAJARAN DARING Chusnul Kotimah. $101-110$.

Krisnasari, E. S. D., \& Tjahjo Purnomo, J. (2017). Hubungan Kohesivitas Dengan Kemalasan Sosial Pada Mahasiwa. Jurnal Psikologi, 13(1), 13. https://doi.org/10.24014/jp.v13i1.2586

Luo, Z., Marnburg, E., Øgaard, T., \& Okumus, F. (2021). Exploring antecedents of social loafing in students' group work: A mixed-methods approach. Journal of Hospitality, Leisure, Sport and Tourism Education, 28(March). https://doi.org/10.1016/j.jhlste.2021.100314

Moslem, M. C., Komaro, M., \& Indonesia, U. P. (2019). Faktor-Faktor Yang Menyebabkan Rendahnya Motivasi Belajar Siswa Dalam Mata Pelajaran Aircraft Drawing Di Smk. Journal of Mechanical Engineering Education, 6(2), 258-265. https://doi.org/10.17509/jmee.v6i2.21803

Mudjiono, D. (2006). Belajar dan Pembelajaran. Rineka Cipta.

Myers. D.G. (2012). Social Psychology (10th ed.). Salemba Humanika. 
Paksi, E. W. H., Okfrima, R., \& Mariana, R. (2020). Hubungan antara Kohesivitas dan Motivasi Berprestasi dengan Kemalasan Sosial pada Mahasiswa Jurusan Psikologi Universitas Negeri Padang. Psyche 165 Journal, 13(1), 53-59.

Saldana, J. (2009). The Coding Manual for Qualitative Researchers. Sage.

Sanjaya, W. (2010). Kurikulum dan Pembelajaran, Teori dan Praktek Pengembangan Kurikulum KTSP. Kencana.

Sarwono, Sarlito. W \& Meinarno, E. A. (2015). Psikologi Sosial. Salemba Humanika.

Sasmita, N. A., Mustika, M. D., Psikologi, F., \& Indonesia, U. (2019). Jurnal Diversita. 5(2), $105-114$.

Taiyeb, A. M., Bahri, A., \& Razak, R. B. (2012). Dalam Belajar Biologi. Analisis Motivasi Berprestasi Siswa Sman 8 Makassar Dalam Belajar Biologi, 13, 77-82.

Taylor, S. E., Peplau, L. A., \& Sears, D. O. (2012). Social Psychology 12th edition (Alih Bahasa Tri Wibowo B.S.). Kencana Prenada Media Group.

Xiangyu, Y., Huanhuan, L., Shan, J., Fei, P., \& Zhongxin, L. (2014). Group Laziness: The Effect of Social Loafing on Group Performance. Social Behavior \& Personality: An International Journal, 42(3), 465-471. 